Maciej Cesarz

ORCID: 0000-0002-9995-719X

Uniwersytet Wrocławski

DOI: $10.19195 / 2450-274 X .4 .5$

\title{
Kontrola mobilności a suwerenność terytorialna państw
}

Abstrakt: Niniejszy artykuł podejmuje problematykę kontroli mobilności i jej związku z suwerennością terytorialną państwa narodowego. Opierając się na teoretycznej analizie suwerenności terytorialnej w globalizującym się świecie, przyjęto założenie, zgodnie z którym rosnąca współzależność państw w erze transgranicznych przepływów osobowych i postindustrializacji nie jest równoznaczna z zanikiem suwerenności. Sprawia ona natomiast, że wykonywanie funkcji państwowych w dziedzinie kontroli granicznej, a zwłaszcza kontroli mobilności rozumianej jako nadzór nad transgranicznym przepływem osób, staje się coraz bardziej złożone. Wnioski wskazują, że pomimo liberalizacji przepływów ludzkich, które są cechą wyróżniającą globalizację, państwa dążą do zachowania swoich prerogatyw w dziedzinie kontroli ruchu osobowego, postrzeganej jako domena ich suwerennej władzy. Umiędzynarodowienie, ekstraterytorializacja, selektywna restrykcyjność, prywatyzacja i outsourcing mechanizmów kontroli mobilności są głównymi przejawami reakcji państw narodowych na procesy globalizacji, motywowanej chęcią utrzymania monopolu w zakresie decydowania, kto może wjechać na ich terytorium. Wymienione płaszczyzny reakcji państw narodowych na presję wywieraną na ich granice $\mathrm{w}$ ramach globalizującej się rzeczywistości wskazują raczej na ekspansję lub multiplikację działań państwa w wielu sferach kontroli i nadzoru, mających świadczyć o rosnącym zasięgu suwerennej władzy państwa narodowego, rozciągającej się daleko poza podlegające terytorium. Tym samym kontrola mobilności rozumiana jako nadzór nad transgranicznym przepływem osób nadal jest uznawana za jedną z najważniejszych cech sprawnie działającej władzy państwowej, rozciągającej się na podlegającym jej terytorium, a rządy narodowe dążą do maksymalizacji korzyści płynących z partycypacji w procesach globalizacyjnych, przy zachowaniu możliwie szerokich uprawnień kontrolnych.

Słowa kluczowe: kontrola mobilności, kontrola graniczna, zarządzanie granicami UE, strefa Schengen, suwerenność terytorialna 


\section{Mobility control and territorial sovereignty of states}

Abstract: This article explores the relation of mobility control to the territorial sovereignty of the national state. Based on a theoretical analysis of sovereignty in the globalizing world, it claims that growing interdependence of states in the era of transnational flows and postindustrialization is not tantamount to the disappearance of sovereignty. It only makes the exercise of state functions in the field of mobility and border control increasingly complex. Despite the liberalization of cross-border flows that are the distinguishing feature of globalization, states strive to preserve their prerogatives of border control which is a domain of their sovereign power. Internationalization, extra-territorialization, selective restrictiveness, privatization and outsourcing of border control mechanisms are the main manifestations of the reactions of nation states to globalization processes, caused by the desire to maintain the monopoly on deciding who may enter their territory. The article concludes that limited sovereignty mentioned in the context of the European Union Member States means that sovereignty should now be seen as being distributed among various entities. In this approach, sovereignty in the field of mobility control is not a zero-sum game; the state remains sovereign although the power and control of border crossing associated with it are currently located on various levels.

Keywords: mobility control, border control, European Union border management, Schengen area, territorial sovereignty

\section{Suwerenność państwa wobec własnego terytorium a kontrola granic}

Granice są zasadniczym elementem konstytuującym nowoczesną państwowość, we współczesnym świecie nie funkcjonują bowiem państwa narodowe, których terytorium nie wytyczałyby i nie definiowałyby linie graniczne, wyznaczające zakres jurysdykcji sądowniczej, policyjnej, władzy administracyjnej, reżimów podatkowych, systemów zabezpieczeń społecznych czy edukacji. Kontrola i ochrona granicy państwowej są istotnymi narzędziami zapewnienia spójności i integralności terytorialnej, społecznej, ekonomicznej oraz nieodłącznym elementem polityki bezpieczeństwa państwa.

W tradycyjnym ujęciu problematyka granic oraz ich przekraczania jest bezpośrednio związana z państwem jako suwerenną organizacją terytorialno-polityczną, gdzie suwerenność definiuje się jako
niezależność państwa od wszelkiej innej władzy w jego stosunkach z innymi pod- miotami prawa międzynarodowego oraz jego samodzielność w regulowaniu spraw wewnętrznych w sposób nieograniczony przez żaden czynnik zewnętrzny, ale bez naruszania praw innych państw i zgodnie z podstawowymi zasadami prawa mię- dzynarodowego ${ }^{1}$.

Jest ona atrybutem państwa jako odrębnej i niezależnej jednostki geopolitycznej, która ponosi wyłączną odpowiedzialność za to, co dzieje się na jej terytorium. To ostatnie rozumiane jest na ogół jako przestrzeń, nad którą państwo rozciąga

\footnotetext{
${ }^{1}$ S. Konopacki, Problem suwerenności w Unii Europejskiej, „Studia Europejskie” 2008, nr 3, s. 9.
} 
swoją władzę zwierzchnią (suwerenną) ${ }^{2}$ lub po prostu „przestrzeń, w której funkcjonują państwa”3. Obszar ten wyznaczają granice, tradycyjnie definiowane jako ostre, precyzyjnie wyznaczone $\mathrm{w}$ przestrzeni linie, klarujące się w procesie demarkacji, delimitacji i administrowania nimi ${ }^{4}$.

To jednowymiarowe, techniczne podejście określające granice państwowe jako „linie styku dwóch suwerennych państw, oddzielające je równocześnie od siebie” może wydawać się nieadekwatne w czasach nasilenia procesów transnarodowych i współzależności w stosunkach międzynarodowych; sprowadza też problematykę kontroli przekraczania granic głównie do wymiaru polityczno-prawnego. Pozostaje ono jednak głównym punktem odniesienia podjętych rozważań, gdyż w praktyce kontrolę graniczną umiejscawia się przede wszystkim w systemie państwowym. W artykule przyjęto perspektywę realistyczną, zgodnie z którą państwa są podstawowymi uczestnikami życia międzynarodowego, a zarazem podmiotami zorganizowanymi terytorialnie, które wyznaczają linię demarkacyjną między tym, co „wewnętrzne” a tym, co „międzynarodowe"6.

Niezależnie od tezy o osłabieniu kompetencji państwa w zakresie kontroli ruchu granicznego, wywołanej intensyfikacją transgranicznych przepływów osobowych, państwa nadal pozostają centralnymi i najbardziej wpływowymi podmiotami środowiska międzynarodowego, które włączają pod swoje zwierzchnictwo wszystkie jednostki i grupy społeczne ${ }^{7}$. To w obrębie granic państwo sprawuje suwerenną władzę, której integralną częścią jest zwierzchnictwo terytorialne. W ich ramach reguluje też życie społeczeństw zamieszkujących podlegające jej terytorium, gdyż suwerenność względem własnego terytorium przejawia się w podporządkowaniu władzy zwierzchniej wszystkich osób i rzeczy położonych na terenie państwa ${ }^{8}$.

Niesłabnące przywiązanie aparatu państwowego do kwestii uregulowania systemu kontroli granic wynika również z faktu, że te ostatnie pozwalają oddzielić suwerenność danego państwa od suwerenności jego sąsiadów. Kontrola mobilności

${ }^{2}$ I. Popiuk-Rysińska, Uczestnicy stosunków międzynarodowych, ich interesy i oddziaływania, [w:] Stosunki międzynarodowe. Geneza, struktura, dynamika, red. E. Haliżak, R. Kuźniar, Warszawa 2006, s. 91.

${ }^{3}$ L. Antonowicz, Państwa i terytoria. Studium prawnomiędzynarodowe, Warszawa 1998, s. 162, cyt. za: K. Baraniak, Terytorium, autonomia terytorialna i zwierzchnictwo terytorialne w naukach politycznych, „Zeszyty Naukowe Państwowej Wyższej Szkoły Zawodowej im. Witelona w Legnicy” 22, 2017, nr 1, s. 171.

${ }^{4}$ Natomiast w sensie politycznym można wyróżnić np. granice jako bariery, granice jako pomosty, granice jako zasoby i granice jako symbole tożsamości. Por. G. Balawajder, Granica państwa jako kategoria wielowymiarowa, „Pogranicze. Polish Borderland Studies” 1, 2013, nr 1, s. 50.

${ }^{5}$ J. Bański, Granica w badaniach geograficznych - definicja i próba klasyfikacji, „Przegląd Geograficzny" 82, 2010, nr 4, s. 489.

6 S.P. Sałajczyk, Wizje rzeczywistości międzynarodowej, [w:] Stosunki międzynarodowe. Geneza... s. $37-45$

7 I. Popiuk-Rysińska, op. cit., s. 91.

8 A. Klafkowski, Prawo międzynarodowe publiczne, Warszawa 1979, s. 189. 
jako nadzór nad transgranicznym przepływem osób uznawana jest także za jedną z najważniejszych cech sprawnie działającej władzy państwowej, rozciągającej się na podlegającym jej terytorium. Państwo wykonuje władzę na swoim terytorium nie dlatego, że tak stanowi prawo międzynarodowe, lecz dlatego, że państwo istnieje, gdyż posiadanie określonego terytorium wynika z zasady rzeczywistości ${ }^{9}$. Z istoty suwerenności wynika ponadto, że jeśli umowy międzynarodowe nie stanowią inaczej, państwo samo reguluje ruch osobowy i rzeczowy przez swoją granicę, nie ma bowiem normy prawa międzynarodowego, która nakazywałaby wpuszczać cudzoziemców na terytorium państwa. Każde suwerenne państwo samo decyduje kogo przyjmuje na swoje terytorium, na jakich warunkach, w jakim celu, a przede wszystkim, czy i na jakiej podstawie określonemu cudzoziemcowi przysługuje prawo do przekroczenia granicy ${ }^{10}$. Kontrola graniczna jest przy tym symboliczną demonstracją władzy państwa i jego suwerenności, zakładającą ipso facto potencjalną możliwość zamknięcia granic państwowych oraz ścisłej regulacji wjazdów i kontroli przepływów osobowych łącznie z pozbawieniem prawa wjazdu określonych kategorii obcokrajowców ${ }^{11}$.

Wraz $\mathrm{z}$ rozwojem administracyjnym władze państwa, aby kontrolować zasoby i wdrażać polityki, muszą zachować zdolność lokalizowania poszczególnych grup i jednostek składających się na jego populację, dlatego „przestrzenne zakotwiczenie ludzkiej mobilności” jest zasadniczą metodą utrzymania kontroli nad własnym terytorium ${ }^{12}$. Co więcej, kategorie osób umykające tej penetracji dają niepożądane świadectwo ograniczeń aparatu państwowego i osłabiają monopol jego władzy $^{13}$. Tym samym suwerenność terytorialna egzekwowana w ramach ściśle wytyczonych granic stanowi fundamentalne osiągnięcie o charakterze politycznym, ukazujące potencjał państwa w zakresie zagwarantowania ludności porządku i bezpieczeństwa.

Historycznie decyzja o tym, kto ma prawo wjazdu i przebywania na danym terytorium, była atrybutem władzy państwa, a zarazem jednym z podstawowych wyznaczników jego międzynarodowej podmiotowości. Rozwojowi państwa towarzyszyło przejęcie i monopolizacja prerogatyw w zakresie sprawowania kontroli granicznej, przy czym punktem zwrotnym w tym kontekście okazał się okres pierwszej wojny światowej (wyraźnie kontrastujący z liberalnymi, cechującymi się stosunkowo mało rozpowszechnionym użyciem paszportów i słabo rozwinię-

9 K. Baraniak, op. cit., s. 175.

10 E. Dynia, Ewolucja polityki migracyjnej Unii Europejskiej - wnioski de lege ferenda, [w:] W obliczu kryzysu. Przyszłość polityki azylowej i migracyjnej Unii Europejskiej, red. A. Kosińska, Lublin 2017, s. 10 .

11 J. Torpey, Coming and going: On the state monopolization of the legitimate „means of movement, „Sociological Theory” 1998, s. 240; B. Ryan, V. Mitsilegas, Extraterritorial Immigration Control: legal challenges, Boston 2010, s. 58.

12 J. Torpey, op. cit., s. 244.

13 S. Mau et al., Globalized borders? Selectivity, internationalization, exterritorialization, 2009, www.aup.edu, s. 7. 
tym systemem regulacji przepływów migracyjnych realiami XIX w.). Postępujący monopol władzy państwowej w krajach Europy Zachodniej skutecznie ograniczył uprawnienia pozostałych podmiotów, sprawiając, że ostatecznie utraciły one prawo ustanawiania „legitymowanych środków kontroli przepływu osób”. Politykę przekraczania granic uznano w rezultacie za domenę państwa zachowującego powszechnie respektowane prawo kontroli każdej osoby, która je przekracza, nawet jeżeli ${ }^{14}$ nie daje najmniejszych powodów do podejrzeń.

\section{Kontrola graniczna jako element suwerenności a procesy globalizacyjne}

W XXI w. czynnikiem warunkującym współuczestnictwo różnych poziomów systemu kontroli granic w procesie decyzyjnym jest też ogromna mobilność osób i dóbr, ale też zagrożeń, które mogą być kontrolowane na poziomie lokalnym i narodowym, regulowane na poziomie państwowym i ponadnarodowym i koordynowane na poziomie ponadpaństwowym. Charakter granic i ich funkcji zmienia się pod wypływem globalizacji, określanej jako „proces wzrastających, niesymetrycznych zależności i powiązań gospodarek państwowych, powodujący nasilenie wolnego przepływu towarów, usług, ludzi, idei przez granice państwowe i ponad nimi, którego siłą napędową jest rozwój technologii”'15.

W warunkach globalizacji kultury oraz internacjonalizacji polityki i gospodarki nastąpiło otwarcie granic i związane z tym osłabienie kontroli granicznej, stanowiącej dotychczas barierę dla przepływu ludzi, dóbr, kapitału i idei, co nakazuje postawić pytanie o przyszłość granic $\mathrm{w}$ kontekście suwerenności państw ${ }^{16}$. Jest ono uzasadnione, gdyż zmiany funkcji granic oznaczają poważne zmiany w sile i trwałości państwa narodowego, a także w przebiegu procesów politycznych, gospodarczych i społecznych, które do tej pory postrzegano jako wyraz wyłączności wynikającej z suwerenności państwa. Oznacza to, że współczesna percepcja granic państwowych dotyczy nie tylko zmian zachodzących w obrębie instytucji państwa i jego polityk, lecz wiąże się również z koniecznością redefinicji obywatelstwa, suwerenności i tożsamości narodowej ${ }^{17}$.

Wskazuje się, że istotą zmian globalizacyjnych pozostaje postępujący proces wydziedziczenia państwa z jego autonomicznej władzy i poddanie go siłom glo-

14 Ibidem, s. 7.

15 W. Anioł, Paradoksy globalizacji, Warszawa 2002, s. 37; R. Kuźniar, Globalizacja, geopolityka i polityka zagraniczna, „Sprawy Międzynarodowe” 1, 2000, s. 5-28; A. Moraczewska, Korporacje transnarodowe w procesach globalizacji, [w:] Oblicza procesów globalizacji, red. M. Pietraś, Lublin 2002, s. 85-103.

16 G. Balawajder, op. cit., s. 50.

17 Ibidem, s. 51. 
balnego rynku ${ }^{18}$, czego wyrazem jest słabnięcie państwa, a zarazem wzrost znaczenia korporacji ponadnarodowych i rynków finansowych w systemie międzynarodowym. Następuje też eliminacja krajowych restrykcji w ruchu towarowym i osobowym, sprzyjająca pogłębieniu międzynarodowej integracji gospodarczej ${ }^{19}$. Wobec rosnących wzajemnych powiązań państw o charakterze bilateralnym i multilateralnym dla niektórych badaczy dotychczasowa koncepcja władztwa państwowego w zakresie kontroli granicznej wydaje się nie do utrzymania, głównie z uwagi na osłabienie stopnia niezależności decyzji, uznawanego za konstytutywny dla klasycznego rozumienia państwowej suwerenności ${ }^{20}$. Byłoby to zgodne z przyjętą w praktyce stosunków międzynarodowych zasadą, że niezależność jest pochodną relacji z innymi podmiotami - im ściślejsze relacje i wynikające $\mathrm{z}$ nich zobowiązania, tym bardziej ograniczona możliwość w pełni samodzielnego podejmowania decyzji ${ }^{21}$. Tymczasem wolny przepływ dóbr, kapitału, informacji czy osób wydaje się zmniejszać znaczenie kontroli nad terytorium, a proces ten wspomaga instytucjonalizacja egzekwowania praw człowieka i zasady niedyskryminacji podważających legalność zakazów i ograniczeń w zakresie swobodnego przemieszczania się.

Reakcją na wzrost przepływów transgranicznych jest też modyfikacja funkcji granic - zaczynają one zatracać swą funkcję dzieląco-blokującą, stając się przede wszystkim granicami o charakterze administracyjnym. Podnosi się przy tym, że globalizacja pozostaje procesem, którego głównym atrybutem jest osłabienie władzy krajowej i znoszenie barier państwowych, a tym samym zacieranie się granic między państwami ${ }^{22}$. Podobnie zanik terytorialnego wymiaru kontroli mobilności ${ }^{23}$, a nawet - jak utrzymują niektórzy - jej dematerializacja ${ }^{24}$ stanowią punkt wyjścia dla tezy o stopniowej erozji znaczenia granic postrzeganych klasycznie jako „bramy strzegące narodowego terytorium” i stanowiących „podstawowy filar państwowości”"25. Tym samym wobec coraz płynniejszego podziału działań państwa na sferę wewnętrzną i zewnętrzną kontrola graniczna traci na znaczeniu.

18 G. Cimek, W labiryncie pojęć - globalizacja jako kategoria teoretyczna, „Zeszyty Naukowe Marynarki Wojennej" 4, 2011, nr 187, s. 173.

19 M. Czerny, Globalizacja a rozwój. Wybrane zagadnienia geografii społeczno-gospodarczej świata, Warszawa 2005, s. 19.

${ }^{20}$ L. Wiśniewski, M.M. Bieczyński, Swoboda przemieszczania się w prawie międzynarodowym, prawie Unii Europejskiej i polskim prawie krajowym. Przegląd zagadnień, Warszawa 2015, s. 168.

21 Ibidem.

22 R.N. Rosecrance, The rise of the virtual state: wealth and power in the coming century, Cambridge 1999, s. 24.

${ }^{23}$ F. Infantino, Outsourcing Border Control. Politics and Practice of Contracted Visa Policy in Morocco, New York 2016, s. 1-27.

${ }^{24}$ L. Amoore, Biometric borders: Governing mobilities in the war on terror, „Political Geography” 2006, s. 336-351; M.B. Salter, The global visa regime and the political technologies of the international self: Borders, bodies, biopolitics, „Alternatives: Global, Local, Political” 31, 2006, nr 2, s. 167-189.

25 S.C. Colombeau, Policing the internal Schengen borders - managing the double bind between free movement and migration control, „Policing and Society” 2015, s. 1, http://www.tandfonline.com/ action/journalInformation?journalCode=gpas20 (dostęp: 1 października 2018). 
Teza o „erozji barier terytorialnych” i „zaniku państwa postrzeganego jako przestrzeń zamknięta" 26 nie znajduje jednak potwierdzenia w kontekście przepływów osobowych. Zapomina się bowiem, że motywy i skutki transgranicznego przepływu osób są inne od pozostałych form mobilności, z kolei intensyfikacja ruchu osobowego nie jest bynajmniej jednoznaczna z utratą zdolności państwa do sprawowania kontroli nad własnym terytorium. Migracje silnie oddziałują na rzeczywistość społeczną, gospodarczą i polityczną, dlatego też w odróżnieniu od pozostałych przepływów ruch osobowy i kontrola graniczna należą do kwestii społecznie drażliwych, pozostając uważnie obserwowanym aspektem działań państwa.

Podobnie marginalizacja aktualnego potencjału państw w sferze regulacji mobilności wydaje się błędna — rządy narodowe w rzeczywistości dążą do maksymalizacji korzyści płynących z partycypacji w procesach globalizacyjnych, przy zachowaniu możliwie szerokich uprawnień kontrolnych. Jednocześnie pozostają one kluczowymi aktorami w międzynarodowej i regionalnej sieci powiązań politycznych i ekonomicznych, narzucając też tempo i dynamikę integracji. To państwa stanowią zasadniczą platformę i zaplecze zmian, gdyż dysponują infrastrukturą niezbędną do realizacji procesów globalizacyjnych na poziomie legislacyjnym, przy zachowaniu standardów porządku i bezpieczeństwa publicznego oraz dobrobytu. Wreszcie efekty globalizacji materializują się właściwie w obszarze terytorialnym państw, który na ogół nie doświadcza rewolucyjnych zmian ${ }^{27}$. Niemniej państwa zmuszone są reagować na wzrost przepływów migracyjnych i warunkujące je zmiany w światowych realiach politycznych i normatywnych. Należy tu wymienić trzy zasadnicze wymiary wspomnianej reakcji państw na dynamikę międzynarodowych uwarunkowań.

Pierwszy z nich sprowadza się do narastającej selektywnej restrykcyjności kontroli granicznej, profilowanej pod kątem określonej kategorii osób korzystających z prawa wjazdu. O ile poszczególne jednostki lub ich grupy niemal nie doświadczają barier $\mathrm{w}$ toku przekraczania granic, o tyle inne napotykają wiele utrudnień w tym zakresie, niweczących de facto możliwość realizacji swobody przemieszczania się. Propagowana (również na poziomie UE) konstrukcja „inteligentnych granic” (smart borders) dzięki nowoczesnej technologii umożliwia wyselekcjonowanie pasażerów „wysokiego” lub „niskiego ryzyka”, czyniąc zadość wymogom bezpieczeństwa w czasach zagrożenia terroryzmem, przestępczością zorganizowaną czy nielegalną imigracją, przy jednoczesnym zachowaniu niezbędnej, pożądanej (głównie z powodów ekonomicznych) przepuszczalności granic ${ }^{28}$. Wyraźne jest przy tym zogniskowanie selekcji wokół ściśle określonych grup podróżnych, doświadczających odrębnych procedur weryfikacji podczas wjazdu oraz zróżnicowanych restrykcji w sferze mobilności.

26 S. Sassen, Losing Control?: Sovereignty in an Age of Globalization, New York 1996, s. 52.

27 P. Hirst, G. Thompson, Globalization and the future of the nation state, „Economy and Society" 24, 2006, nr 3, s. 408-442.

${ }^{28}$ M.B. Salter, Passports, mobility, and security: How smart can the border be?, „International Studies Perspectives" 5, 2004, s. 71-91, DOI: 10.1111/j.1528-3577.2004.00158.x. 
Drugi wymiar stanowi zaawansowana współpraca państw, przybierająca formę internacjonalizacji (a w przypadku UE nawet supranacjonalizacji) mechanizmów kontroli granicznej. W realiach globalizacji władze krajowe nie są w stanie skutecznie panować nad przestrzenią poprzez samodzielne działania i coraz częściej zmuszone są odwoływać się do środków i rozwiązań międzynarodowych. Przestrzenna mobilność cudzoziemców wymaga od państwa przyjmującego uregulowania wielu kwestii związanych $\mathrm{z}$ ich wjazdem i pobytem ${ }^{29}$, tymczasem we współczesnym świecie (zwłaszcza w realiach integrującej się Europy) wielu tych zagadnień decydenci narodowi nie są w stanie (a jak sądzą niektórzy, nawet nie powinni $z$ uwagi na przeniesienie części kompetencji na poziom ponadnarodowy) rozstrzygać samodzielnie ${ }^{30}$.

O ile w klasycznej teorii ustroju państwa możliwość niezależnego decydowania o przepływie osób na danym terytorium uznawano za wyznacznik suwerenności, o tyle współczesne państwa funkcjonują w sieci dwustronnych i wielostronnych powiązań, wpływających na zdolność do niezależnej regulacji prawa do przemieszczania się. Rezultatem jest zaawansowana internacjonalizacja lub supranacjonalizacja i krystalizowanie się sui generis „makro-terytoriów” (Mercosur, strefa Schengen), czemu towarzyszy kształtowanie się kontroli granicznej nowej generacji. Deinstalacja krajowych barier w przemieszczaniu się, delegacja uprawnień na poziom międzynarodowy lub ponadnarodowy i relokacja kontroli w kierunku granic zewnętrznych kształtujących się makro-terytoriów stanowią główny wyróżnik tej reakcji państw na impulsy globalizacyjne.

Trzeci wymiar, uprawnienia państw, szczególnie zaliczanych do kręgu liberalnej cywilizacji Zachodu, w dziedzinie kontroli granic doznają coraz większych ograniczeń, głównie za sprawą dobrowolnie przyjmowanych zobowiązań. Współczesne standardy konstytucyjne gwarantują minimalne poszanowanie praw podstawowych wszystkim osobom przebywającym na terytorium danego państwa, niezależnie od ich obywatelstwa. Ogranicza to w znacznym stopniu swobodę regulacyjną państw w sprawach takich, jak nielegalna imigracja, azyl, prawo do łączenia rodzin czy wymogi wizowe ${ }^{31}$. W konsekwencji władze krajowe muszą korzystać z innych dostępnych środków kontroli przepływów ludzkich, głównie poprzez ich ekstraterytorializację (np. wymóg uprzedniego złożenia wniosku wizowego w placówce dyplomatycznej położonej w państwie pochodzenia aplikanta), prywatyzację i outsourcing (sankcje nakładane na przewoźników, wymuszające prewencyjną kontrolę dokumentów podróży), celem ograniczenia poszczególnym kategoriom osób możliwości powoływania się na przysługujące im prawa związane $\mathrm{z}$ wjazdem na terytorium państwa. Innymi słowy, relokacja kontroli granicznej jest reakcją na przyjęty przez liberalne

29 I. Wróbel, Europeizacja prawa imigracyjnego Republiki Federalnej Niemiec w latach 19992009, Wrocław 2010, s. 66.

30 Ibidem.

31 C. Joppke, Challenge to the Nation-State: Immigration in Western Europe and the United States, Oxford 1998, s. 10-13. 
społeczeństwa zachodniej demokracji katalog standardów normatywnych, chroniących migrantów dopiero $\mathrm{w}$ chwili przekroczenia przez nich granicy państwowej ${ }^{32}$.

Wymienione płaszczyzny reakcji państw narodowych na presję wywieraną na ich granice w ramach globalizującej się rzeczywistości wskazują raczej na ekspansję lub multiplikację działań państwa w wielu sferach kontroli i nadzoru, mających świadczyć o rosnącym zasięgu suwerennej władzy państwa narodowego, rozciągającej się daleko poza podlegającym terytorium. „Mobilny i płynny” charakter granic $^{33}$ będący przesłanką ich odterytorialnienia w sposób szczególny manifestuje się na kontynencie europejskim poprzez stosowanie acquis Schengen. Analizując np. założenia wspólnej polityki wizowej, Elspeth Guild doszła do wniosku, że konsekwencją budowy strefy Schengen było „oddzielenie granic od terytorium”, gdzie punktem odniesienia dla stosowanego względem jednostek reżimu granicznego jest już „nie tyle ich fizyczne położenie, lecz obywatelstwo i indywidualne cechy”. W rezultacie każda lokacja może stać się miejscem kontroli granicznej.

Ponadto granice stały się głównym punktem odniesienia dla różnicowania pożądanych i godnych zaufania podróżnych (bona fide travellers) od tych, którzy nie podróżują w dobrej wierze albo wręcz stanowią zagrożenie ${ }^{34}$. Zauważalna jest tendencja państw UE do egzekwowania coraz bardziej zaawansowanej selekcji wybranych kategorii podróżnych, interpretowana jako pierwotna reakcja władz narodowych na nowe perspektywy, a zarazem ryzyko związane z globalnym charakterem przepływów migracyjnych i ukierunkowana na działania prewencyjne w odniesieniu do wjazdu osób postrzeganych jako zagrożenie bezpieczeństwa, standardu życia lub tożsamości danego państwa ${ }^{35}$.

Pomimo liberalizacji przepływów środków produkcji oraz internacjonalizacji reżimów granicznych będących wyróżnikiem globalizacji państwa w rzeczywistości dążą do zachowania swoich prerogatyw w zakresie kontroli granicznej rozumianej jako emanacja przynależnej im suwerennej władzy. Jak wskazuje Torpey, kontrola mobilności nadal pozostaje w zglobalizowanym świecie naczelnym atrybutem nowoczesnej państwowości ${ }^{36}$. Co więcej, nawet internacjonalizacja lub supranacjonalizacja reżimu granicznego nie musi oznaczać osłabienia monopolu państw w tej dziedzinie. Przywoływany wcześniej układ Schengen oraz system zintegrowanego zarządzania granicami zewnętrznymi UE wspierany przez Europejską Straż Graniczną i Przybrzeżną Frontex nie przeczy tej tezie - za kontrolę granic zewnętrznych nadal są odpowiedzialne peryferyjne państwa członkow-

32 S. Mau et al., op. cit., s. 10.

${ }^{33}$ E. Guild, The Border Abroad - Visas and Border Controls, [w:] In Search of Europe's Borders, red. K. Groenendijk, E. Guild, P. Minderhound, Hague-London-New York 2003.

34 J. Torpey, The Invention of the Passport Surveillance, Citizenship and the State, Cambridge 2000.

35 A. Ceyhan, Policing by Dossier: Identification and Surveillance in an Era of Uncertainty and Fear, [w:] Controlling Frontiers: Free Movement into and Within Europe, red. D. Bigo, E. Guild, London 2005, s. 209-232.

36 S. Mau et al., The global mobility divide: How visa policies have Evolved over time, „Journal of Ethnic and Migration Studies" 2015, s. 3. 
skie Unii. Ponadto w przeprowadzonych już w 2002 r. badaniach wykazano, że wskutek implementacji Konwencji Schengen państwa członkowskie doświadczyły znacznego wzmocnienia uprawnień kontrolnych względem zarówno obywateli państw członkowskich, jak i cudzoziemców ${ }^{37}$.

W odniesieniu do wewnątrzunijnego ruchu osobowego sytuacja prezentuje się podobnie - acquis Schengen znosi kontrole na granicach wewnętrznych, umożliwiając pełną realizację prawa do swobodnego przemieszczania się osób, ale bynajmniej nie prowadzi do zniesienia granic między państwami-sygnatariuszami. Ponadto prawo do przemieszczania się, stanowiące fundament obywatelstwa unijnego, nie jest przywilejem obowiązującym w sposób nieograniczony, podlega ono bowiem warunkom określonym $w$ prawie pochodnym UE oraz kryteriom pozostającym w gestii państw członkowskich, które faktycznie decydują o tym, kto może być jego beneficjentem. Prawo swobodnego przepływu osób zależy zatem od kryteriów określonych narodowo, nie ograniczając suwerennych uprawnień państw członkowskich $^{38}$. Ponadto względem osób nieaktywnych ekonomicznie prawo to ograniczone jest wymogiem posiadania dostatecznych środków utrzymania oraz ubezpieczenia zdrowotnego. Określając minimum kosztów utrzymania, państwa członkowskie decydują, kto faktycznie może skorzystać z prawa do swobodnego poruszania się i osiedlania, co prowadzi do powstania dwóch kategorii obywateli: tych, którzy mogą korzystać ze swobody osiedlania się i poruszania, oraz tych, którzy ze względów ekonomicznych są tego prawa praktycznie pozbawieni ${ }^{39}$.

\section{Konkluzje}

Stale rosnąca współzależność państw w dobie globalizacji i postindustrializacji nie jest równoznaczna z zanikiem suwerenności, sprawia jedynie, że wykonywanie funkcji państwowych w zakresie kontroli mobilności staje się coraz bardziej skomplikowane. Pomimo liberalizacji przepływów transgranicznych, będących wyróżnikiem globalizacji, państwa dążą do zachowania swoich prerogatyw w zakresie kontroli granicznej będącej domeną ich suwerennej władzy. Internacjonalizacja, ekstaraterytorializacja, selektywna restrykcyjność, prywatyzacja i outsourcing maechanizmów kontroli granicznej to główne przejawy reakcji państw

37 K. Groendijk, New Borders Behind Old Ones: Post-Schengen Controls Behind the Internal Borders and Inside the Netherlands and Germany, [w:] In search of Europe's borders, red. K. Groenendijk, E. Guild, P.E. Minderhoud, London 2003.

38 Obywatelstwo europejskie zdefiniowane jest na zasadzie obywatelstwa narodowego, jest jego funkcją. Obywatelstwo europejskie jest akcydentalne wobec obywatelstwa krajowego i zależne od istnienia więzi prawnej między jednostką a państwem członkowskim. Innymi słowy, posiadanie przez jednostkę obywatelstwa unijnego jest całkowicie uzależnione od posiadania obywatelstwa państwa członkowskiego. Oznacza to, że o posiadaniu obywatelstwa unijnego decydują całkowicie państwa członkowskie i ich odpowiednie przepisy prawne. Zob. S. Konopacki, op. cit., s. 14.

${ }^{39}$ Ibidem, s. 13. 
narodowych na procesy globalizacyjne, powodowanych dążeniem do zachowania monopolu w kwestii decydowania o wjeździe na własne terytorium. Należy też nadmienić, że decyzję o zacieśnianiu więzi z innymi państwami w ramach sprawowanej kontroli granicznej, nawet poprzez supranacjonalizację, tj. tworzenie ponadnarodowych instytucji i środków w tej dziedzinie, należy traktować jako decyzję suwerenną, nawet jeżeli ostatecznie może ona prowadzić do ograniczenia suwerenności ${ }^{40}$. Z kolei ograniczona suwerenność, o jakiej często mówi się w kontekście państw członkowskich Unii Europejskiej, w gruncie rzeczy oznacza, że obecnie suwerenność należy widzieć jako rozdzieloną między różne podmio$\mathrm{ty}^{41}$. Terytorialnie zakreślone podziały w istocie zdają się tracić na znaczeniu, zarazem między władzami stale odbywają się negocjacje na różnych poziomach ponadnarodowym, narodowym i regionalnym, przy czym każdy z nich pełni inne funkcje ${ }^{42}$. W tym ujęciu suwerenność w zakresie kontroli mobilności nie jest grą o sumie zerowej - państwo pozostaje suwerenne, chociaż władza i związana z nią kontrola przekraczania granic ulokowane są na wielu poziomach.

\section{Bibliografia}

Amoore L., Biometric borders: Governing mobilities in the war on terror, „Political Geography” 2006. Anioł W., Paradoksy globalizacji, Warszawa 2002.

Antonowicz L., Państwa i terytoria. Studium prawnomiędzynarodowe, Warszawa 1998.

Balawajder, G., Granica państwa jako kategoria wielowymiarowa, „Pogranicze. Polish Borderland Studies" 1, 2013, nr 1.

Bański J., Granica w badaniach geograficznych - definicja i próba klasyfikacji, „Przegląd Geograficzny" 82, 2010, nr 4.

Baraniak K., Terytorium, autonomia terytorialna i zwierzchnictwo terytorialne w naukach politycznych, „Zeszyty Naukowe Państwowej Wyższej Szkoły Zawodowej im. Witelona w Legnicy” 22, 2017, nr 1.

Ceyhan A., Policing by Dossier: Identification and Surveillance in an Era of Uncertainty and Fear, [w:] Controlling Frontiers: Free Movement into and Within Europe, red. D. Bigo, E. Guild, London 2005.

Cimek G., W labiryncie pojęć - globalizacja jako kategoria teoretyczna, „Zeszyty Naukowe Marynarki Wojennej" 4, 2011, nr 187.

Colombeau S.C., Policing the internal Schengen borders - managing the double bind between free movement and migration control, „Policing and Society” 2015, http://www.tandfonline.com/action/ journalInformation?journalCode=gpas20.

Czerny M., Globalizacja a rozwój. Wybrane zagadnienia geografii społeczno-gospodarczej świata, Warszawa 2005.

Dynia E., Ewolucja polityki migracyjnej Unii Europejskiej - wnioski de lege ferenda, [w:] W obli-

40 L. Wiśniewski, M.M. Bieczyński, op. cit., s. 168.

41 S. Konopacki, op. cit., s. 12.

42 L. Hooghe, G. Marks, Unraveling the central state, but how? Types of multi-level governance, „American Political Science Review” 96, 2003, nr 2, s. 234, cyt. za: J. Czaputowicz, Labirynty konceptualizowania Unii Europejskiej i suwerenności jej państw członkowskich, „Studia z Polityki Publicznej” 2015, nr 3 (7), s. 15. 
czu kryzysu. Przyszłość polityki azylowej i migracyjnej Unii Europejskiej, red. A. Kosińska, Lublin 2017.

Guild E., The Border Abroad - Visas and Border Controls, [w:] In Search of Europe's Borders, red. K. Groenendijk, E. Guild, P. Minderhound, Hague-London-New York 2003.

Groendijk K., New Borders Behind Old Ones: Post-Schengen Controls Behind the Internal Borders and Inside the Netherlands and Germany, [w:] In search of Europe's borders, red. K. Groenendijk, E. Guild, P.E. Minderhoud, London 2003.

Hirst P., Thompson G., Globalization and the future of the nation state, „Economy and Society” 24, 2006, nr 3.

Hooghe L., Marks G., Unraveling the central state, but how? Types of multi-level governance, „American Political Science Review" 96, 2003, nr 2, s. 234, cyt. za: J. Czaputowicz, Labirynty konceptualizowania Unii Europejskiej i suwerenności jej państw członkowskich, „Studia z Polityki Publicznej” 2015, nr 3 (7), s. 15.

Infantino F., Outsourcing Border Control. Politics and Practice of Contracted Visa Policy in Morocco, New York 2016.

Joppke C., Challenge to the Nation-State: Immigration in Western Europe and the United States, Oxford 1998.

Klafkowski A., Prawo międzynarodowe publiczne, Warszawa 1979.

Konopacki S., Problem suwerenności w Unii Europejskiej, „Studia Europejskie” 2008, 3.

Kuźniar R., Globalizacja, geopolityka i polityka zagraniczna, „Sprawy Międzynarodowe” 1, 2000.

Mau S. et al., The global mobility divide: How visa policies have evolved over time, „Journal of Ethnic and Migration Studies" 2015.

Mau S. et al., Globalized borders? Selectivity, internationalization, exterritorialization, 2009.

Moraczewska A., Korporacje transnarodowe w procesach globalizacji, [w:] Oblicza procesów globalizacji, red M. Pietraś, Lublin 2002.

Popiuk-Rysińska I., Uczestnicy stosunków międzynarodowych, ich interesy i oddziaływania, [w:] Stosunki międzynarodowe. Geneza, struktura, dynamika, red. E. Haliżak, R. Kuźniar, Warszawa 2006.

Rosecrance R.N., The rise of the virtual state: wealth and power in the coming century, Cambridge 1999.

Ryan B., Mitsilegas V., Extraterritorial Immigration Control: legal challenges, Boston 2010.

Sałajczyk S.P., Wizje rzeczywistości międzynarodowej, [w:] stosunki międzynarodowe. Geneza, struktura, dynamika, red. E. Haliżak, R. Kużniar, Warszawa 2006.

Salter M.B., The global visa regime and the political technologies of the international self: Borders, bodies, biopolitics, „Alternatives: Global, Local, Political” 31, 2006, nr 2.

Salter M.B., Passports, mobility, and security: How smart can the border be?, „International Studies Perspectives" 5, 2004.

Sassen S., Losing Control?: Sovereignty in an age of Globalization, New York 1996.

Torpey J., Coming and going: On the state monopolization of the legitimate „means of movement, „Sociological Theory" 1998.

Torpey J., The Invention of the Passport Surveillance, Citizenship and the State, Cambridge 2000.

Wiśniewski L., Bieczyński M.M., Swoboda przemieszczania się w prawie międzynarodowym, prawie Unii Europejskiej i polskim prawie krajowym. Przeglad zagadnień, Warszawa 2015.

Wróbel I., Europeizacja prawa imigracyjnego Republiki Federalnej Niemiec w latach 1999-2009, Wrocław 2010. 